УДК 372.881.111.1

DOI https://doi.org/10.26661/2414-1135-2021-83-40

\title{
ІНШОМОВНА КОМПЕТЕНТНІСТЬ: ПЕДАГОГІЧНІ ТА ЛІНГВІСТИЧНІ АСПЕКТИ
}

\author{
Швецова I. B. \\ кандидат педагогічних наук, \\ доиент кафедри англійської мови у судноводінні \\ Херсонська державна морська академія \\ вул. Ушакова, 20, Херсон, Україна \\ orcid.org/0000-0002-6801-5204 \\ isvecova581@gmail.com
}

Ключові слова: морська англійська мова, стандартні фрази для спілкування в морі, ІМО, викладання морської англійської мови, викладачі англійської мови спеціального призначення у вищих навчальних закладах, майбутні судноводї, морські заклади вищуої освіти, фахівці морської галузі.
У статті розглянуто проблему іншомовної компетентності майбутніх фахівців із навігації і управління морськими суднами. Обгрунтовано ідею про те, що головна мета навчання іноземної мови полягає в оволодінні нею як засобом комунікації та опануванні іншомовною компетентністю, необхідною для професійної діяльності. Наведено аналіз поглядів дослідників стосовно сутності «компетенція», визначено те, що поняття компетентності значно ширше, оскільки воно розуміється комплексно та складається 3 різних компонентів: сукупності знань, умінь та навичок, необхідних для здійснення відповідної професійної діяльності, властивостей мотивації, ціннісних орієнтирів, готовності до дії, до оцінювання та рефлексії. Визначено, що іншомовна компетенція передбачає не лише наявність навичок та вмінь, але й адекватне їх використання в конкретній мовленнєвій ситуації. На основі сучасних педагогічних підходів та напрямів визначено структурні блоки іншомовної компетентності майбутніх фахівців із навігації і управління морськими суднами: аксіологічно-мотиваційний компонент, когнітивний та регулятивно-діяльнісний. Проаналізовано ключові елементи когнітивного компонента іншомовної компетентності майбутніх фахівців, що функціонують відповідно до особливостей мови та професійної діяльності фахівців. У статті з'ясовано специфіку англійської морської термінології, що зумовлює необхідність іiі врахування іiі в процесі навчання здобувачів освіти вищих навчальних закладів із метою формування їхньої іншомовної компетентності. У статті охарактеризовано лінгвістичні та педагогічні аспекти формування іншомовної компетентності. 3'ясовано, що в процесі навчання морської англійської мови здобувачі освіти мають набути знання про лінгвістичні особливості англійської мови, що підходять для морського дискурсу/ тексту і комунікації та включають типову або часто використовувану технічну лексику і певні граматичні структури. Основну увагу в роботі акцентовано на лінгвістичних особливостях морської англійської мови, а також методології викладання цього навчального предмета для загальних і спеціальних цілей (з урахуванням специфіки когнітивних процесів у морській сфері) і має бути враховано у процесі формування іншомовної компетенції. 


\title{
FOREIGN LANGUAGE COMPETENCE: PEDAGOGICAL AND LINGUISTIC ASPECTS
}

\author{
Shvetsova I. V. \\ Candidate of Pedagogical Sciences, \\ Associate Professor at the Department of English in Navigation \\ Kherson State Maritime Academy \\ Ushakova Ave, 20, Kherson, Ukraine \\ orcid.org/0000-0002-6801-5204 \\ isvecova581@gmail.com
}

\begin{abstract}
Key words: Maritime
English, standard marine

communication phrases, IMO,

teaching Maritime English, teachers of English for Specific

Purposes at higher educational establishments, future

navigators, maritime institutions

of higher education, specialists

in the maritime industry.
\end{abstract}

\begin{abstract}
The article deals with the problem of foreign language competence of future specialists in navigation and ship handling at sea. The article substantiates the idea that the main goal of teaching foreign language consists in mastering foreign language as a communication tool and developing foreign language competence necessary for professional activity. An analysis of researchers' views on the essence of "competence" is presented and it is determined that the concept of competence is much broader as it is understood comprehensively and consists of various components: a set of knowledge, skills and abilities necessary to carry out relevant professional activities, properties of motivation, values, readiness for action, evaluation and reflection. Based on the study of the essence of the concepts, it is determined that the foreign language competence implies not only the presence of skills and abilities, but also their adequate use in a specific speech situation. On the basis of modern pedagogical approaches and directions the structural blocks of foreignlanguage competence of future specialists in navigation and ship handling at sea have been identified: axiological-motivational, cognitive, regulatoryactivational components. The key elements of the cognitive component of foreign-language competence of future specialists are analyzed, functioning in accordance with the peculiarities of the language and professional activities of specialists. The peculiarities of English marine terminology are identified in the article, which stipulates the necessity of its consideration in the process of higher education students' training with the aim of forming their foreign language competence. The article characterizes the linguistic and pedagogical aspects of foreign language competence formation. The article reveals that in the process of learning maritime English, higher education students are to acquire knowledge about linguistic features of English, suitable for maritime discourse/text and communication and include typical or frequently used technical vocabulary and certain grammatical structures. The focus of the paper is on the linguistic features of maritime English and the methodology of teaching this subject for general and special purposes (taking into account specific cognitive processes in the maritime domain) and should be taken into account during the development of foreign language competence.
\end{abstract}

Постановка проблеми. Забезпечення успішності професійної діяльності майбутніх фахівців із навігації і управління морськими суднами неможливе без високого рівня володіння іноземною мовою, адже для досягнення максимальної ефективності своєї професійної діяльності сучасний мореплавець має володіти знаннями, ефективними методами швидкого професійного реагування на різні ситуації, вміти застосувати різноманітні фундаментальні і прикладні знання в попередженні нещасних випадків, а також володіти вмінням самостійного пошуку та опрацювання необхідної інформації професійного характеру. 3 огляду на ці вимоги перед майбутніми фахівцями 3 навігації і управління морськими суднами гостро постає завдання оволодіння іншомовною компетенцією, що $є$ обов'язковим компонентом їхньої повноцінної професійної 
діяльності, з одного боку, та необхідним результатом їхньої професійної підготовки - з іншого.

Мета і завдання статті - розкрити ключові елементи когнітивного компонента іншомовної компетентності майбутніх фахівців із навігації і управління морськими суднами. Завдання статті - охарактеризувати лінгвістичні та педагогічні аспекти формування іншомовної компетентності.

Об'єкт дослідження - професійна підготовка майбутніх фахівців із навігації й управління морськими суднами.

Предмет дослідження - зміст формування іншомовної компетентності майбутніх фахівців із навігації і управління морськими суднами.

Виклад основного матеріалу дослідження.

Теоретичні положення проблеми формування компетентностей у процесі фахової підготовки розглядали О. Авраменко, В. Борщовецька, А. Касперський, А. Кононенко, М. Корець, М. Малежик, І. Нищак, Ю. Рамський, Л. Сидорчук, В. Сидоренко, Ю. Шпильовий, С. Яшанов та ін., а особливості дослідження у сфері англійської мови професійного спрямування, а саме лінгвістичні та педагогічні аспекти - В. Желясков, В. Кудрявцева, А. Юрженко, М. Сотер та ін.

Основними цілями навчання в закладі вищої морської освіти за визначеннями М. Сотер мають бути такі: цілеспрямована підготовка фахівців до міжкультурної комунікації через опанування ними знань про національний менталітет, картину світу; формування здатності до побудови як мовної, так і немовної поведінки з урахуванням норм соціумів, представники яких спілкуються тією чи іншою мовами; вміння виявляти та порівнювати культурні відмінності поведінки, норм і цінностей, розуміти погляди, наміри, думки, позицію представників іншої культури, долати конфлікти в процесі комунікації, забезпечити під час спілкування суб' єкт-суб'єктну взаємодію. Тобто іноземна мова як засіб професійної міжкультурної комунікації у професійній діяльності фахівців морської галузі - це основний інструмент соціальної інтеграції людини в полікультурний простір, універсальне знаряддя адекватного спілкування і рівноправної продуктивної взаємодії між представниками різних лінгвокультурних спільнот [1]. Таким чином, головна мета навчання іноземної мови полягає в оволодінні нею як засобом комунікації та опануванні іншомовною компетентністю, необхідною для професійної діяльності.

Загальноєвропейські рекомендації 3 мовної освіти визначають, що використання мови, в тому числі і їі вивчення, включає в себе дії, що виконуються особами, які в ролі окремих індивідів чи соціальних агентів розвивають низку компетенцій як загальних, так і комунікативних, мовленнєвих. Сформовані компетенції використовуються в міру необхідності в різних контекстах залежно від різних умов та різних потреб для здійснення різних видів мовленнєвої діяльності, до яких належать мовленнєві процеси продукції та/або сприйняття текстів, пов'язаних із певними темами у специфічних сферах. Керівництво цими діями з боку учасників веде до посилення або модифікації ї компетенцій. Компетенції трактуються як сума знань, умінь та характерних рис, що дають змогу особистості виконувати певні дії. Загальні компетенції-це ті, що не є специфічними для мовлення, але такі, що необхідні для будь-якого роду діяльності, в тому числі й мовленнєвої. Комунікативні мовні компетенції забезпечують людині можливість діяти, застосовуючи специфічні лінгвістичні засоби $[2$, с. 36$]$.

Імпонує тлумачення Г. Салащенко сутності поняття «компетенція», що розуміється комплексно та складається 3 різних компонентів: сукупності знань, умінь та навичок, необхідних для здійснення відповідної професійної діяльності, властивостей особистості, а також потенційної здатності людини вирішувати різні задачі [3].

На підставі аналізу сутність поняття «компетенція» визначається як знання та навички, властиві для певної діяльності. Поняття компетентності значно ширше порівняно 3 поняттями «знання», «уміння» та «навички», оскільки воно розуміється комплексно та складається 3 різних компонентів: сукупності знань, умінь та навичок, необхідних для здійснення відповідної професійної діяльності, властивостей мотивації, ціннісних орієнтирів, готовності до дії, до оцінювання та рефлексії. Отже, іншомовна компетенція передбачає не лише наявність навичок та вмінь, але й адекватне їх використання в конкретній мовленнєвій ситуації.

3 погляду теорії іншомовної мовленнєвої діяльності, на думку Г. Салащенко, компетенції в говорінні, читанні, письмі та аудіюванні формуються на базі лексичної та граматичної компетенції і належать до основ мовленнєвої компетенції. Компетенція в говорінні доповнюється компетенцією у вимові, компетенція в письмі - орфографічною компетенцією, в аудіюванні - умінням розрізнювати фонетичні знаки, компетенція в читанні умінням розпізнавати графічні знаки. Провідним компонентом у комунікативній компетенції є мовленнєві вміння, які формуються на основі мовних знань та навичок, а також лінгвокраїнознавчих та країнознавчих знань [3].

На основі сучасних педагогічних підходів та напрямів визначено структурні блоки іншомовної компетентності майбутніх фахівців із навігації й 
управління морськими суднами: аксіологічно-мотиваційний компонент, когнітивний та регулятивнодіяльнісний, зміст яких полягає в такому:

- усвідомлення необхідності емоційно-ціннісного ставлення до оволодіння іншомовними знаннями, для професійної діяльності;

- розвиток спеціалізованих професійних знань, умінь та навичок оволодіння здобувачами вищої освіти англійською мовою спеціального вжитку;

- реалізація практичних навичок, умінь і досвіду прояву іншомовної компетенції у конкретних ситуаціях.

Зупинимося більш детально на когнітивному блоці іншомовної компетентності, який передбачає володіння мовними знаннями (знання в межах програмного мінімуму та навички оперування ними, тобто знання самої мови, її будови, функціонуваннями мовних норм). До них зараховуємо фонетику, граматику (граматичні структури, характерні для ділового стилю і професійної літератури), лексику (знання професійної термінології, що дають змогу опрацьовувати міжнародні документи). До когнітивного блоку іншомовної компетенції зараховуємо мовленнєві знання, а саме вдосконалення комунікативних умінь в основних видах мовленнєвої діяльності: говорінні, аудіюванні, читанні та письмі. Мовна та мовленнєва компетенції є складниками лінгвістичного компонента, що зумовлений такими чинниками, як рівень освіти, професія, індивідуальний досвід. Чим ширше коло асоціативних зв'язків мовної одиниці у свідомості носія мови, тим більш розвинутою $є$ організація лексикону мовної особистості і більш гнучким є запас потенційного мовленнєвого варіювання формально-змістових аспектів мовної одиниці в іiі мовленні [4].

Поділяємо думку науковців, що формування у здобувачів освіти CALP (когнітивної/академічної мовної компетенції) має бути спрямованим на синтез розумових навичок і засобів їх вербалізації другою мовою шляхом інтеграції їх попереднього досвіду у відповідній предметній області і особистого інтересу [5, с. 15-16]. Так, у процесі використання предметно-мовного інтегрованого навчання відбувається взаємодія когнітивних процесів, що застосовуються в процесі вивчення іноземної мови та дисципліни немовного циклу, наприклад, навігація та лоція, що формує розвиток розумових навичок здобувача освіти, підвищує мотивацію щодо вивчення дисципліни.

Значне місце займає знання морської термінології іноземною мовою, оскільки вона є основою будь-якої професійної інформації. 3 метою уникнення численних інцидентів на борту, які викликані непорозумінням із багатомовною командою, Міжнародна морська організація затвердила
«Стандартні фрази для спілкування в морі Міжнародної морської організації (IMO)». Таким чином, завдання навчальних закладів - надати здобувачам освіти необхідні професійні знання і мовні навички для роботи на борту, що дозволить максимально скоротити кількість людських помилок, які призводять до аварій. Стандартні фрази морського спілкування затверджені для того, щоб стандартизувати мову, що використовується для зв'язку, а також для внутрішнього суднового спілкування на суднах із багатомовною командою.

Стандартні фрази морського спілкування не потребують оволодіння складними граматичними трансформаціями та подані у спрощеному варіанті англійської мови, де часто пропущені артиклі, дієслово «bе», не використовуються синоніми, не допускаються вживання скорочених форм.

Результати проведеного дослідження висвітлено у попередніх публікаціях і свідчать про те, що навчання здобувачів освіти стандартним фразам для спілкування в морі слід здійснювати на основі реальної практики в морській галузі і шляхом застосування відповідних сучасних методів вивчення мови. Вивчення стандартних фраз має здійснюватися системно і послідовно, для чого необхідно розробити тематично зорієнтовану i методично обгрунтовану систему завдань і послідовність їх виконання [6].

Отже, вказана специфіка англійської морської термінології зумовлює необхідність ії врахування в процесі навчання здобувачів освіти вищих навчальних закладів із метою формування їхньої іншомовної компетентності.

3 метою підвищення рівня володіння мовою дослідниками було запропоновано різні проєкти, один $з$ яких - це Європейський проєкт SeaTALK, у рамках якого запропоновано створення комплексну основу для освіти і навчання морської англійської мови, де встановлений стандартний підхід до викладання, навчання та оцінювання кваліфікацій по всій Європі для кожного типу і рангу моряків відповідно до Загальноєвропейські компетенції володіння іноземною мовою (Carmen Astratinei) [7]. Представлене завдання включає в себе навички читання і говоріння, аналіз автентичних матеріалів, а саме звіти про подію на морі і моделювання ситуації. Це завдання покликане допомогти закріпити стандартні фрази для спілкування на борту і поза судном, фактично використовуючи фрази в контексті. Подальша робота полягає в обговоренні інцидентів у групах і відборі стандартних фраз відповідно до ситуацій. Робота завершується складанням діалогу і обміном думками перед аудиторією [7].

Досліджуючи питання викладання морської англійської мови, науковці звертають увагу на те, що сам термін «морська англійська мова» - це в 
першу чергу умовне позначення, різновид англійської мови [8]:

- відповідає конкретній морській обстановці (тобто в процесі навігації, вирішення ситуації, запиту стосовно розміщення у портах, операцій із перевезення вантажу);

- використовується в певному контексті ситуації (тобто на борту судна на морі чи в порту, на березі в доках або в центрі обслуговування руху суден (VTS) центр);

- залучає учасників із конкретного судового або портового мовного співтовариства, часто зазначене специфічним жаргоном (наприклад, розмова боцмана і жаргон докерів);

- виникає в мовних подіях, пов'язаних із морським судноплавством, що впливають на (успішну) комунікацію, (наприклад, під час відправки, передачі та прийомі повідомлень, мовної взаємодії в рубці);

- функціонування і формування в конкретних соціолінгвістичних обставин (тобто конкретні відносини між співрозмовниками, що часто розвиваються в умовах стресу і паніки).

Висновки і перспективи подальших розробок. Враховуючи усе вищезазначене, можна дійти таких висновків: когнітивний компонент формування іншомовної компетентності функціонує відповідно до особливостей мови та професійної діяльності фахівців. Результати проведеного дослідження свідчать про те, що у процесі навчання морської англійської здобувачі освіти мають набути знання про лінгвістичні особливості англійської мови, що підходять для морського дискурсу/тексту і комунікації та включають типову або часто використовувану технічну лексику і певні граматичні структури. Отже, лінгвістичні особливості морської англійської мови, а також методології викладання цього навчального предмета для загальних і спеціальних цілей (з урахуванням специфіки когнітивних процесів у морській сфері) мають бути враховані у процесі формування іншомовної компетенції.

Напрямом подальшого дослідження $є$ з'ясування стану сформованості іншомовного компонента в 3ВО на основі аналізу філософської, психологічної, педагогічної, методичної літератури, практики підготовки майбутніх фахівців із навігації й управління морськими суднами і виявлення напрямів, що потребують дослідження.

\section{ЛІТЕРАТУРА}

1. Сотер М.В. Формування готовності майбутніх інженерів-судномеханіків до міжкультурної комунікації : дис. ... канд. пед. наук : 13.00.04 / Херсонський державний університет; Тернопільський національний педагогічний уні- верситет ім. В. Гнатюка. Херсон; Тернопіль, 2018. $297 \mathrm{c}$.

2. Загальноєвропейські Рекомендації 3 мовної освіти: вивчення, викладання, оцінювання. / Науковий редактор українського видання С.Ю. Ніколаєва. Київ: Ленвіт, 2003. 273 с.

3. Салащенко Г.М. Особливості формування іншомовної комунікативної компетенції студентів та курсантів немовних закладів вищої освіти засобами проектних технологій. Правовий часопис Донбасу. 2019. № 3(68). C. $153-160$.

4. Сніховська I.Е. Лінгвістична компетенція як фактор мовної гри. URL: https://core.ac.uk/ download/pdf/12081679.pdf (дата звернення 09.08.2021).

5. Брик Т.О., Лєбошина Н.В. Методичні переваги використання CLIL у навчанні мовної компетенції майбутніх офіцерів в рамках іншомовної професійно-орієнтованої підготовки. Іншомовна комунікативна компетентність у фаховій діяльності : матеріали тез доповідей міжуніверситетського науково-практичного семінару, м. Харків, 27 лист. 2018 р. Харків, 2018. C. $15-16$.

6. Кудрявцева В.Ф., Швецова І.В. Стандартні фрази для спілкування в морі як навчальна потреба. Збірник наукових пращь. Педагогічні науки. 2019. Випуск LXXXVIII. C. 104-109.

7. Trenkner, Peter \& Pritchard, Boris \& Cole, Clive. (2007). Maritime English instruction, ensuring instructors, competence. Ibérica: Revista de la Asociación Europea de Lenguas para Fines Específicos (AELFE), N. 14, 2007, P. 123-148. URL: https://www.researchgate.net/publication/ 28210716_Maritime_English_instruction_ensuring_instructors_competence (дата звернення 02.08.2021).

8. Carmen Astratinei. Ways of teaching ESP Maritime English SMCP (Standard Marine Communication Phrases). Foreign language competence as integral component of the University graduate profile. 2014. P. 25-30. URL: https://www.unob.cz/ cjv/Documents/publications/Sborn\%C3\%ADk_2014_z\%C3\%A1kladn\%C3\%AD.pdf (дата звернення 04.08.2021).

\section{REFERENCES}

1. Soter M.V. (2018) Formuvannja ghotovnosti majbutnikh inzheneriv-sudnomekhanikiv do mizhkuljturnoji komunikaciji [Formation of future marine engineers' readiness to intercultural communication] ( $\mathrm{PhD}$ Thesis), Kherson State University, Ternopil Volodymyr Hnatiuk National Pedagogical University, Ternopil.

2. Nikolayeva S.Yu. (2003) Zaghaljnojevropejsjki Rekomendaciji z movnoji osvity: vyvchennja, 
vykladannja, ocinjuvannja [Common European Framework of Reference for Languages: Learning, Teaching and Assessment], Kyiv : Lenvit.

3. Salashchenko G.M. (2019) Osoblyvosti formuvannja inshomovnoji komunikatyvnoji kompetenciji studentiv ta kursantiv nemovnykh zakladiv vyshhoji osvity zasobamy proektnykh tekhnologhij [Pecularities of formation of foreign language communicative competence of students of non-linguistic higher educational institutions by means of project technologies]. Law journal of Donbass, no. 3(68), pp. 153-160.

4. Snikhovska I.E. (2001) Linhvistychna kompetentsiya yak faktor movnoyi hry. [Linguistic Competence As Speech Play-Acting Factor]. URL: https://core.ac.uk/download/pdf/120816 79.pdf (accessed 09 August 2021).

5. Bryk T.O., Ljeboshyna N.V. (2018) Metodychni perevaghy vykorystannja CLIL u navchanni movnoji kompetenciji majbutnikh oficeriv $\mathrm{v}$ ramkakh inshomovnoji profesijno-orijentovanoji pidghotovky. [Methodological advantages of the use of CLIL in teaching the language competence of future officers in the framework of outsourced professional-oriented training]. Proceedings of an inter-university scientific and practical seminar:
Foreign-language communicative competence in professional activities (Ukraine, Kharkiv, November 21, 2018) Kharkiv : Yaroslav Mudryi National Law University, pp. 1516.

6. Kudriavtseva V.F., Shvetsova I. V. (2019) Standartni frazy dlja spilkuvannja $\mathrm{v}$ mori jak navchaljna potreba. [Standard maritime communication as a training need]. Pedagogicali sciences. Vol. LXXXVIII. pp. 104-109.

7. Trenkner, Peter \& Pritchard, Boris \& Cole, Clive. (2007). Maritime English instruction, ensuring instructors, competence. Ibérica: Revista de la Asociación Europea de Lenguas para Fines Específicos (AELFE), No. 14, pp. 123-148. URL: https://www.researchgate. net/publication/28210716_Maritime_English instruction_ensuring_instructors_competence (дата звернення 02 August 2021).

8. Carmen Astratinei. Ways of teaching ESP Maritime English SMCP (Standard Marine Communication Phrases). (2014). Foreign language competence as integral component of the University graduate profile. pp. 25-30. URL: https://www.unob.cz/cjv/Documents/publications/Sborn\%C3\%ADk 2014_z\%C3\%A1kladn\%C3\%AD.pdf. 